\title{
Management Strategy of Jatiluwih Tourist Attraction as Part of World Cultural Heritage in Tabanan Regency, Bali Province
}

\author{
Dewa Ayu Diyah Sri Widari (Corresponding Author) \\ Student of Tourism Doctorate Program of Udayana University \\ E-mail: dewaayusriwidari@gmail.com
}

Made Antara

Professor at Tourism Doctorate Program of Udayana University

E-mail: antara_unud@yahoo.com

Syamsul Alam Paturusi

Professor at Tourism Doctorate Program of Udayana University

E-mail: syamsul@unud.ac.id

Received: Jan. 21, 2019 Accepted: Feb. 27, 2019 Published: March 15, 2019

doi:10.5296/ijssr.v7i1.14248 URL: http://dx.doi.org/10.5296/ijssr.v7i1.14248

\begin{abstract}
Various attempts have been made to achieve the goals of the management of Jatiluwih Tourist Attractions as part of the World Cultural Heritage, but there are some obstacles in its implementation. This research aims to develop strategies and programs in the management of sustainable Jatiluwih Tourist Attraction as part of the World Cultural Heritage. This study used qualitative methods supported by quantitative data through the use of Interpretive Structural Modeling (ISM) analysis. Data collection was conducted through interviews, Focus Group Discussion, and document studies. The ISM (expert survey) questionnaire as a research instrument was used to obtain information about the contextual relations of each element in the Interpretive Structural Modeling (ISM) analysis involving 11 experts. The results of the study indicate that the management of Jatiluwih Tourist Attraction as part of the World Cultural Heritage requires strategies and programs for sustainability. The formulated
\end{abstract}




\section{Macrothink}

International Journal of Social Science Research

ISSN 2327-5510

strategies are management more structured to increase tourist visits and improve community welfare; increasing the competence of human resources to increase participation; infrastructure development and diversification of tourism products; and increasing support for the preservation of cultural heritage sites through increase community awareness, land use policies, and the involvement of all stakeholders. Programs are formulated based on the strategies set.

Keywords: management, tourist attraction, world cultural heritage 


\section{Introduction}

Cultural tourism is the cornerstone of Bali's tourism development. The Regional Government of Bali has established Regional Regulations on Bali Cultural Tourism. The first time, it was stipulated in the Regional Regulation No. 3 of 1974, revised into Regional Regulation No. 3 of 1991, renewed into Regional Regulation No. 2 of 2012. A series of revisions or improvements indicate the importance of the role of culture in tourism. In addition to improving Regional Regulations on Bali Cultural Tourism, in June 2012 Bali received special recognition from UNESCO with the establishment of subak as part of the World Cultural Heritage with the label of "Cultural Landscape of Bali Province: the Subak System as a Manifestation of the Tri Hita Karana Philosophy".

In determining the Cultural Landscape of Bali or subak as part of the World Cultural Heritage, public attention in Bali and Indonesia is focused on the vast rice fields in Jatiluwih Village located in Penebel Sub-District, Tabanan Regency. This village has a beautiful natural panorama with uniquely rice field terraces. With uniquely rice terraces, subak which is a farmer organization of rice fields in Jatiluwih Village, is used as the main tourist attraction.

Determination of subak as a World Cultural Heritage by UNESCO is a combination between nature and man's work, in its development should provide benefits for the conservation of nature and the success of social, economic, and cultural resources (Yamashita, 2013). It also faced challenges in its management or utilization (Wall and Black, 2005) mentioning that some literature on world heritage tends to focus on discourse and understanding concepts about heritage, high level challenges from management or use of the cultural heritage.

Efforts to preserve cultural heritage related to management give rise to various models of preservation. Huibin et al. (2012) suggest a Cultural Heritage Tourism (CHT) model designed to protect cultural heritage on the tourism management process. The model is composed of three parts, namely support, participation, and balance. Poulios (2014) offers three approaches to heritage conservation, namely: material-based, value-based and a living heritage approach. The cultural heritage management model formulated by Huibin et al. (2012) and Poulios (2014) supported by DuCros et al. (2005) efforts to preserve heritage assets through public-private partnerships, in addition to maintaining the existence of residents and long-term economic benefits through gentrification (encouraging strict building control).

After the establishment of the Jatiluwih Subak as part of the World Cultural Heritage in 2012, the Government of Tabanan Regency established a Tourist Attraction Management Agency based on the Tabanan Regency Regulation Number 84 of 2013. The Management Agency then formed Management Operations of Jatiluwih Tourist Attraction with the aim of conducting activities of planning, development, and supervision so that Jatiluwih Tourist Attraction can be preserved, it is expected that tourist visits continue to increase, and provide benefits to local communities both from the economic, socio-cultural and environmental aspects.

The number of tourist visits to Jatiluwih Tourist Attractions has increased after the establishment of subak as part of the World Cultural Heritage. In 2012 the number of tourist 
visits was 97,909 people, in 2013 there were 101,560 people. In 2014 the number of tourist visits was 165,158 people. In 2015 , the number of tourist visits was 164,358 people, but there was insignificant decrease of $0.48 \%$. In 2016 the number of tourist visits has increased with the number of tourist visits as many as 213,509 people and in 2017 as many as 250,953 people. The average tourist visit per year is 165,574 people (Manajemen Operasional Daya Tarik Wisata Jatiluwih, 2018).

Various efforts have been made to achieve the goals of managing Jatiluwih Tourist Attraction as part of the World Cultural Heritage, but in its implementation, there were several obstacles. The obstacles include lack of accessibility, lack of internet access and limited tourist activities (Wiranatha and Suryawardani, 2018). When capturing the uniqueness of rice field terraces with good views, tourists sometimes enter the paddy fields outside of the trekking path, causing damage to rice fields. A situation like this creates a conflict between farmers and Management Operations of Jatiluwih Tourist Attraction (Widari, 2015). There is a number of chicken farms owned by the local community. Chicken farms caused unpleasant odors, besides the waste generated from livestock has not been managed properly (Antara et al., 2017). With the various obstacles faced, strategies are needed in managing tourist attraction.

This research aims to formulate strategies and programs for sustainable Jatiluwih Tourist Attraction management as part of the World Cultural Heritage.

\section{Research Method}

This study used qualitative methods supported by quantitative data through the use of Interpretive Structural Modeling (ISM) analysis. According to Sage (1977) ISM is an interactive learning process. In this technique, a set of different elements that are directly and indirectly related are formed into a comprehensive systematic model. ISM is a method used in identifying relationships between specific parts to interpret a problem or issues (Jharkharia and Shankar, 2005). The ISM technique is a process that transforms a mental model that is not clear and weak in explanation, becomes a system model that is clearly defined and useful for various purposes (Saxena, 1992).

Data collection was conducted through interviews, Focus Group Discussion, and document studies. The ISM (expert survey) questionnaire as a research instrument was used to obtain information about the contextual relationship of each element in the Interpretive Structural Modeling (ISM) analysis. Referring to this study, experts were selected purposively especially those who understood the contextual relationship between tourism and subak as a tourist attraction in World Cultural Heritage. The study involved 11 experts, namely 3 community leaders, 4 local government officers, and 4 tourism practitioners.

\section{Result and Discussion}

The management of Jatiluwih Tourist Attraction faces a variety of phenomena. In formulating a strategy, the various phenomena related to the management of Jatiluwih Tourist Attraction were structured. The structuring obtained through Interpretive Structural Modeling (ISM) analysis then elaborated to formulate the strategies. 


\section{Macrothink}

International Journal of Social Science Research

ISSN 2327-5510 2019, Vol. 7, No. 1

3.1 The Strategy for Sustainable Jatiluwih Tourist Attraction Management as Part of World Cultural Heritage

Based on the 9 elements in the Interpretive Structural Modeling (ISM) in this study, it was determined 6 elements associated for sustainable tourist attraction management. Each element consists of several sub elements, as follows.

\section{1) Program Goals $(G)$}

Element of the Program Goals for sustainable tourist attraction management consists of 8 sub-elements, namely:

G1: To improve community welfare

G2: To increase number of tourists visit

G3: To conserve tourist attraction

G4: Management more structured

G5: To develop culture

G6: Tourist satisfaction

G7: To involve young generation

G8: To develop creative industries

The results show that the highest Driver Power (8) and the lowest Dependence (1) was G4. This means that the sub-element G4 (management more structured) is the key sub-element of the Program Goals which has the highest Driver Power that push other sub-elements and has the lowest Dependence to other sub-elements. The lowest Driver Power (1 and 2) and the highest Dependence ( 8 and 7)) were G1 and G2. This means that sub-elements G1 (to improve community welfare) and sub-elements G2 (to increase number of tourists visit) have the lowest Driver Power and the highest Dependence with other sub-elements, so all sub-elements will support G1 and G2. Other sub-elements (G3, G5, G6, G7, and G8) become linkage sub-elements which link to each other and with key sub-elements in order to support G1 and G2. The structured diagram of sub-elements of Program Goals can be seen in Figure 1: 


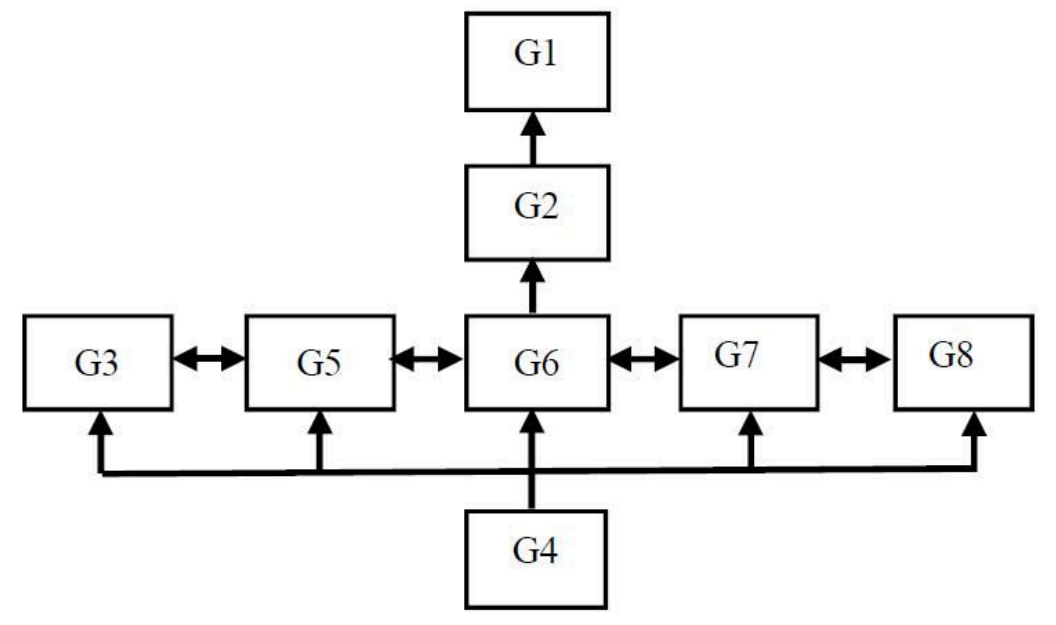

Figure 1. Structured Diagram of Each Sub-Elements of Program Goals

\section{2) Program Needs $(\mathrm{N})$}

Element of the Program Needs for sustainable tourist attraction management consists of 8 sub-elements, namely:

N1: Community participation

N2: Improvement of infrastructure

N3: Synergy between stakeholders

N4: Competence of human resources

N5: Diversification of tourism product

N6: Government support

N7: Support funding for local entrepreneurs

N8: Commitment of stakeholder towards regulatory

The results show that the highest Driver Power (8) and the lowest Dependence (1) was N4. This means that the sub element N4 (competence of human resources) is the key sub-element of the Program Needs which has the highest Driver Power that push the other sub-elements and has the lowest Dependence to other sub-elements. The lowest Driver Power (2) and the highest Dependence (8) are N1 and N2, besides the second lowest Driver Power (3) and the second highest Dependence (6) was N5. This means that sub-element N1 (community participation), N2 (improvement of infrastructure), and N5 (tourism product diversification) were the lowest Driver Power and have the highest Dependence with other sub-elements, so that all sub-elements will support N1, N2, and N5. Other sub-elements (N3, N6, N7, and N8) become linkage sub-elements which link to each other and with key sub-elements in order to support N1, N2, and N5. The structured diagram of sub-elements of Program Needs can be seen in Figure 2: 


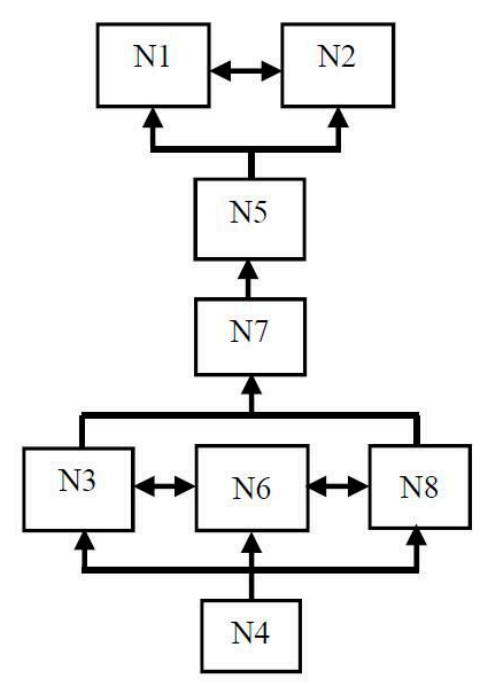

Figure 2. Structured Diagram of Each Sub-Elements of Program Needs

\section{3) Program Constraints (B)}

Element of the Program Constraints for sustainable tourist attraction management consists of 9 sub-elements, namely:

B1: Lack of community awareness

B2: Limited infrastructure

B3: Absence of Spatial Detail Plans

B4: Lack of community expertise

B5: Lack of coordination among stakeholders

B6: Limited local entrepreneurs in the capital investment

B7: Limited tourist activity

B8: Lack of community creativity

B9: Limited innovation

The results show that the highest Driver Power (9) and the lowest Dependence (1) was B4. This means that the sub-element B4 (lack of community expertise) is the key sub-element of the Program Constraints which has the highest Driver Power that push the other sub-elements and has the lowest Dependence to other sub-elements. The second highest Driver Power (8) and the lowest Dependence (4) were B1, B3, and B5. It means that sub elements B1 (lack of community awareness), B3 (absence of Spatial Detail Plans, and B5 (lack of coordination among stakeholders) were the second key sub-elements of Program Constraints that have 


\section{Macrothink}

strong Driver Power that push other sub-elements and have low Dependence to other sub-elements. Other sub elements (B2, B6, B7, B8, and B9) become linkage sub-elements. The structured diagram of sub-elements of Program Constraints can be seen in Figure 3:

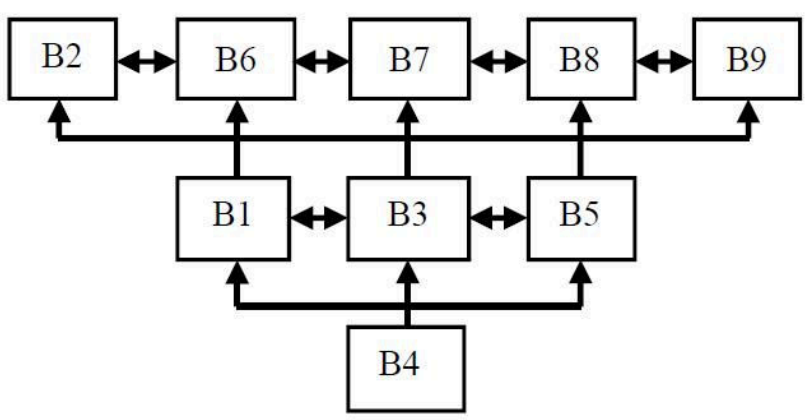

Figure 3. Structured Diagram of Each Sub-Elements of Program Constraints

\section{4) Affected Sectors (C)}

Element of the Affected Sector for sustainable tourist attraction management consists of 8 sub-elements, namely:

C1: Farmers

C2: Farmers' organizations (subak)

C3: Customary village

C4: Village government

C5: Arts groups

C6: Local communities

C7: Household industry group

C8: Business tourism

The results show that the highest Driver Power (8) and the lowest Dependence (1) was C4 (village government) is the key sub-element Affected Sector which has the highest Driver Power that push the other sub-elements and has the lowest Dependence to other sub-elements. The lowest Driver Power (1) and the highest Dependence (8) was C2. This means that sub-element C2 (farmers' organization/subak) has the lowest Driver Power and the highest Dependence with other sub-elements, so that all sub-elements will support $\mathrm{C} 2$. Other sub-elements (C1, C3, C5, C6, C7, and C8) become linkage sub-elements that link to each other and with key sub-elements in order to support C2. The structured diagram of sub-elements of Affected Sectors can be seen in Figure 4: 


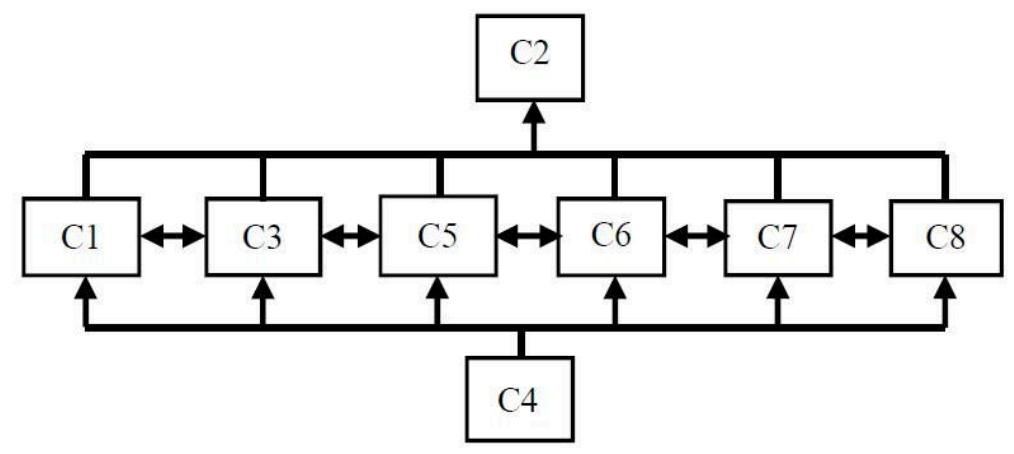

Figure 4. Structured Diagram of Each Sub-Elements of Affected Sectors

5) Intended Changes (E)

Element of the Intended Changes for sustainable tourist attraction management consists of 8 sub-elements, namely:

E1: Increasing income for farmers' organization (subak)

E2: Restriction in land use changes

E3: Development of capabilities and skills of human resources

E4: Environment more organized

E5: Management more professional

E6: Increasing community support

E7: Increasing tourist loyalty

E8: Tourism product more variety

The results show that the highest Driver Power (8) and the lowest Dependence (1) was E3 (development of capabilities and skills of human resources) is the key sub-element of Intended Changes which has the highest Driver Power that push other sub-elements and has the lowest Dependence to other sub-elements. The lowest Driver Power (1) and the highest Dependence (8) was E2. This means that sub-element E2 (restriction in land use changes) was the lowest Driver Power and has the highest Dependence to other sub-elements, so that all sub-elements will support E2. Other sub-elements (E1, E4, E5, E6, E7, and E8) become linkage sub-elements that link to each other and with key sub-elements in order to support E2. The structured diagram of sub-elements of Intended Changes can be seen in Figure 5: 


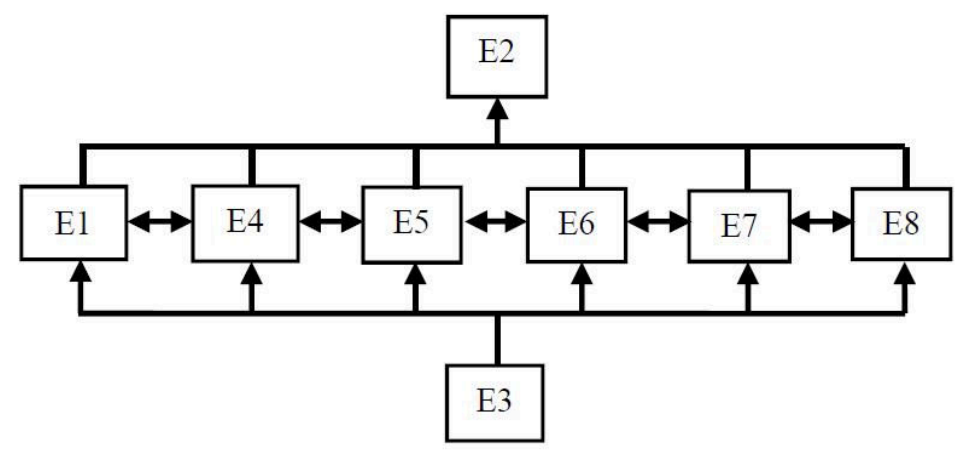

Figure 5. Structured Diagram of Each Sub-Elements of Intended Changes

6) Involvement of Institutions (I)

Element of the Involvement of Institutions for sustainable tourist attraction management consists of 9 sub-elements, namely:

I1: Traditional organization

I2: Regional Tourism Office

I3: Department of Agriculture

I4: Department of Transportation

I5: Department of Culture

I6: Department of Communication and Information

I7: Department of Environment

I8: Research and Development Institute

I9: Tourism Association

The results show that the highest Driver Power (9) and the lowest Dependence (1) was I8 (Research and Development Institute) is the key sub-element of Involved of Institution which has the highest Driver Power that push other sub-elements and has the lowest Dependence to other sub-elements. The lowest Driver Power (1) and the highest Dependence (9) was I1. This means that sub-element I1 (traditional organization) was the lowest Driver Power and has the highest Dependence to other sub-elements, so that all sub-elements will support I1. Other sub-elements (I2, I3, I5, I7, and I9) become linkage sub-elements that link to each other and with key sub-elements in order to support I1. The structured diagram of sub-elements of Involvement can Institution be seen in Figure 6: 


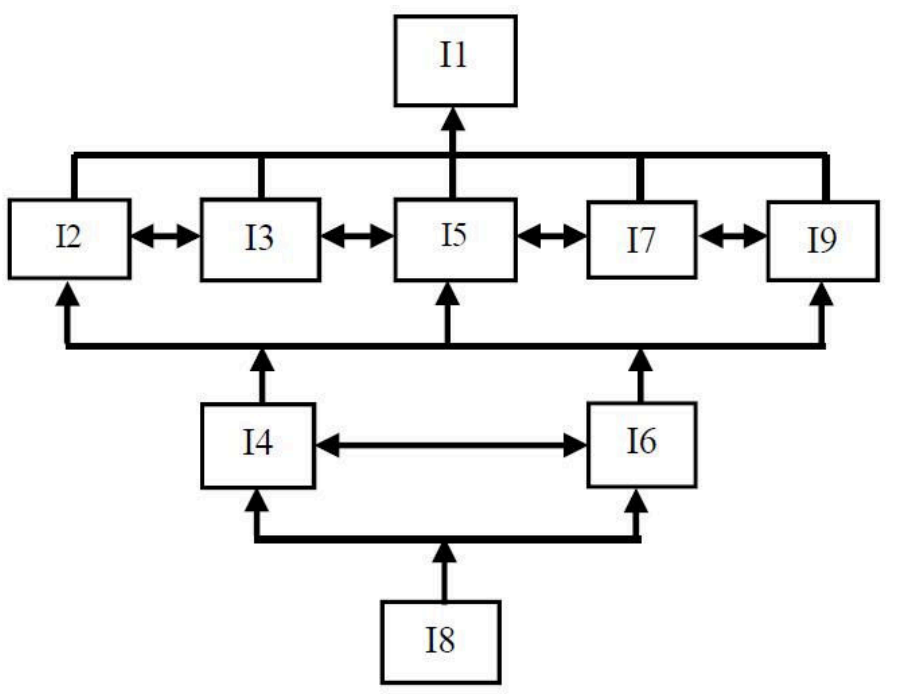

Figure 6. Structured Diagram of Each Sub-Elements of Involvement Institutions

Based on the results of the Interpretive Structural Modeling (ISM) analysis, several sub-elements are considered as key sub-elements for each element. These key elements are further elaborated and formulated as considerations in developing strategies for sustainable tourist attraction management. The structured diagram of Jatiluwih Tourist Attraction management can be seen in Figure 7:

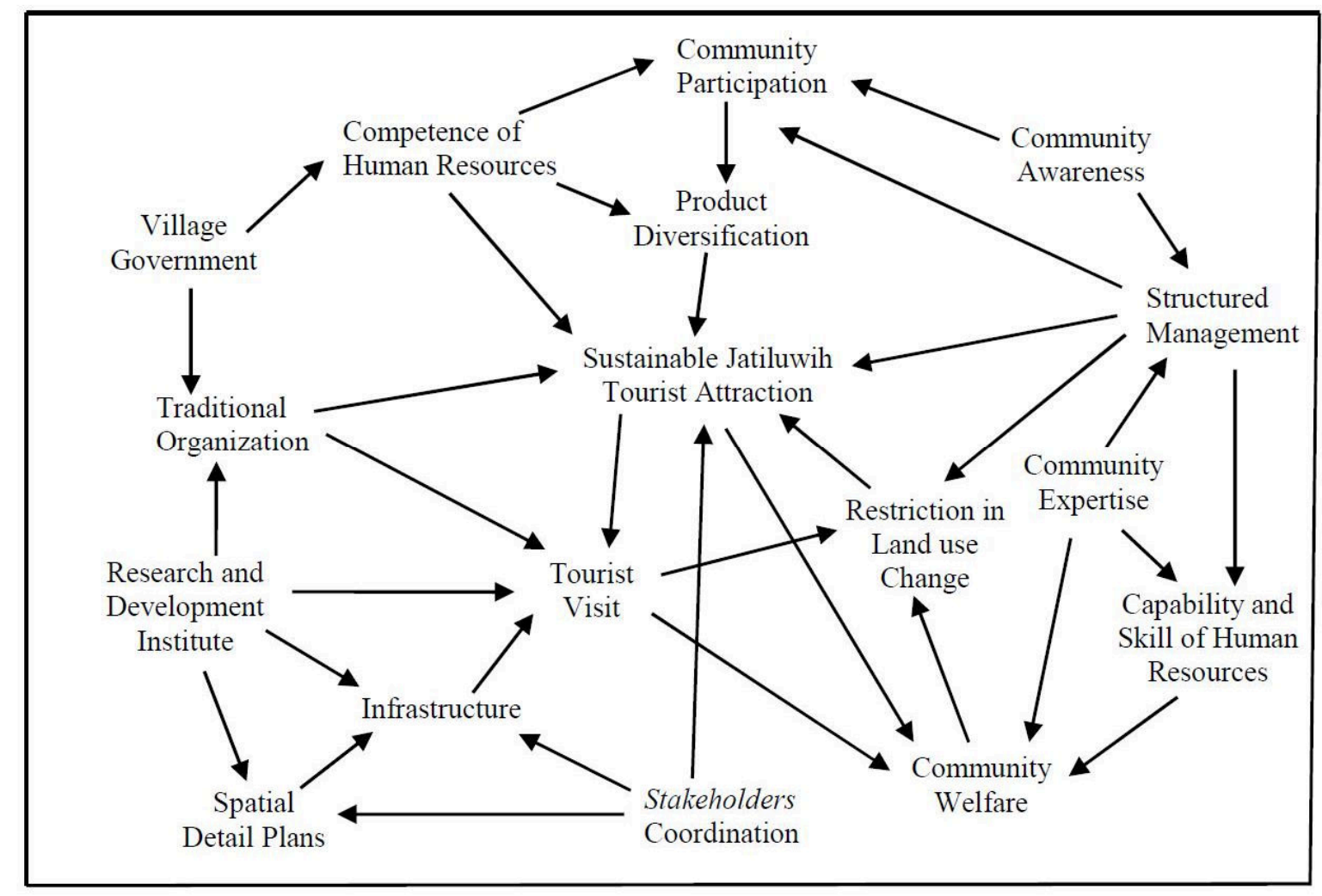

Figure 7. Structured Diagram of Jatiluwih Tourist Attraction Management 
Based on the sustainable tourism strategies for the Cultural Landscape of Bali Province (Dharmiasih et al., 2016) related to the results of Interpretive Structural Modeling (ISM) analysis, the purpose of managing Jatiluwih Tourist Attraction is to make management more structured. This means that in the management of sustainable tourist attraction, the existence of a professional management is needed. Structured management is expected to carry out the functions of planning, implementing and monitoring with professionals through collaborative efforts with institutions involved in managing tourist attractions. For the sustainability of tourist attraction, it is necessary to strengthen management as stated by Boafo (2010) and Lankford and Lankford (2000).

Structured management requires competency in human resources, in accordance with the statement of Richardson and Fluker (2004) suggests that values must be considered in management include human resources. An increase of tourists visit is another goal of managing Jatiluwih Tourist Attraction. This can be achieved with structured management support. To increase tourists visit to Jatiluwih Tourist Attractions, it is necessary to improve and organize infrastructure and diversification of tourism products. Infrastructure limitations such as parking lots and internet access as well as structuring trekking routes require support from the Research and Development Institute and the active role of traditional organizations (traditional villages and subak). Likewise, the diversification of tourism products requires collaboration and synergy between village government and traditional organizations.

The sustainable of Jatiluwih Tourist Attraction management also requires the participation of local community. The involvement of local communities plays an important role for sustainable management, i.e. supporting the statements of Lankford and Lankford (2000), UNEP and WTO (2005), and Sunaryo (2013). Involvement local community in managing the heritage bring about a better chance for conservation and for tourism (Diarta, 2017). Lack of community awareness and expertise is an obstacle that affects community involvement. The involvement of local communities in Management Operations of Jatiluwih Tourist Attraction is an effort to increase community participation. Another obstacle faced in the management of Jatiluwih Tourist Attraction is the absence of Spatial Detailed Plan because there is no reference in the construction and development of tourism facilities and infrastructure. The lack of coordination among stakeholders is one of the causes for the lack of a Spatial Detailed Plan.

Jatiluwih Tourist Attraction Management that utilizes subak as the main attraction, in its utilization cannot be separated from the status of subak as part of the World Cultural Heritage. Based on the structured model of the Jatiluwih Tourist Attraction management, four strategies are formulated, namely: (1) management more structured to increase tourists visit and improve community welfare, (2) increasing the competence of human resources to increase participation, (3) infrastructure development and diversification of tourism products, and (4) increasing support for the preservation of cultural heritage sites through increase community awareness, land use policies, and the involvement of all stakeholders. The strategies formulated according to the cultural heritage preservation model proposed by Huibin et al. (2012) which is composed of three parts, namely support, participation, and balance, it's also supported by DuCross et al. (2005). 
3.2 The Program for Sustainable Jatiluwih Tourist Attraction Management as part of the World Cultural Heritage

The program for sustainable Jatiluwih Tourist Attraction management is formulated based on the established strategies. Each of the strategies and programs of Jatiluwih Tourist Attraction management as follows.

1) Management more structured to increase tourist visits and improve community welfare, the program as follows: (a) making a job description and Standard Operating Procedure (SOP) for each division in Management Operations of Jatiluwih Tourist Attraction; (b) tourist attraction management training; (c) development of agricultural attraction packages; (d) development of promotional media and cooperation in marketing; (e) development of homestay; (f) structuring and managing visitors; and (g) job creation and entrepreneurship training.

2) Increasing the competence of human resources to increase participation, the program as follows (a) training of special guides and foreign languages; (b) training and certification of human resources for accommodation and restaurants; (c) involvement of arts groups in tourist attractions and provision of assistance funds; (d) increasing farmers participation; (e) increasing participation of the younger generation.

3) Infrastructure development and diversification of tourism products, the program as follows (a) development of internet access and parking facilities, and (b) development of tour packages.

4) Increasing support for the preservation of cultural heritage sites through increase community awareness, land use policies, and the involvement of all stakeholders, the program as follows (a) dissemination on tourism programs; (b) environmental conservation training in order to support the World Cultural Heritage; (c) preparation of Detailed Spatial Plans; (d) regular meetings and coordination meetings between stakeholders; (e) monitoring and evaluation related to the management of tourist attractions; and (f) increase communication among the village government.

The strategies and programs formulated are useful for stakeholders for sustainable of tourist attraction management. To achieve the strategies set, the formulated programs can provide direction for Management Operations regarding the activities carried out to achieve the strategies. The strategies formulated for sustainable tourist attraction management are not analyzed regarding the priorities of the strategies and programs. Further research is important to analyze the priorities of the strategies and programs formulated.

\section{Conclusion}

The management of Jatiluwih Tourist Attraction as part of the World Cultural Heritage requires strategies and programs for sustainability. The formulated strategies are management more structured to increase tourist visits and improve community welfare; increasing the competence of human resources to increase participation; infrastructure development and diversification of tourism products; increasing support for the preservation of cultural 
heritage sites through increased community awareness, land use policies, and the involvement of all stakeholders. Programs are formulated based on the strategies set. In the implementation of programs, coordination and synchronization, support and active participation of all stakeholders are needed. Management Operations of Tourist Attraction should make persuasive efforts involving official villages, traditional villages, and the subak or farmers' organization.

\section{References}

Antara, M., Wijaya, G. N. K., \& Windia, W. (2017). Ekowisata Subak Jatiluwih Tabanan, Bali. Denpasar: Pelawa Sari.

Boafo, K. (2010). UNESCO Opportunities for Cultural Heritage Tourism Development in the Carribean. Carribean Tourism Organization's $11^{\text {th }}$ Annual Conference on Sustainable Tourism Development. Barbados.

Dharmiasih, W., Sayoga, A., Pradipta, A., Pratama, A., Arbi, Y., Smith-Christensen, C., DeBrine, P., Hardjasaputra, C., \& Sapardan, W. (2016). Strategi Pariwisata Berkelanjutan Lanskap Budaya Bali: Sistem Subak sebagai Manifestasi Tri Hita Karana. Jakarta: Kantor UNESCO Jakarta.

Diarta, I. K. S. (2017). Between Cultural Preservation and Tourism Industry: Dialectic Relations in Cultural Heritage Tourism Management in Tanah Lot and Borobudur Indonesia. Journal of Tourism, 4(2), 100-109. https://doi.org/10.24922/eot.v4i2.36403

DuCros, H., Bauer, T., Lo, C., Lo, C., \& Rui, S. (2005). Cultural Heritage Assets in China as Sustainable Tourism Products: Case Studies of the Hutongs and the Huanghua Section of the Great Wall. Journal of Sustainable Tourism, 13(2), 171-194. https://doi.org/10.1080/09669580508668484.

Huibin, X., Marzuki, A., \& Abdul Razak, A. (2012). Protective Development of Cultural Heritage Tourism: The Case of Lijiang, China. Theoretical and Empirical Researches in Urban Management, 7(1), 39-54.

Jharkharia, S., \& Shankar, R. (2005). IT-Enablement of Supply Chains: Understanding the Barriers. Journal of Enterprise Information Management, 18(1), 11-27. https://doi.org/10.1108/17410390510571466

Lankford, J. K., \& Lankford, S. V. (2000). Tourism and Sustainability: Can they be Partners? Journal of World Leisure, 42, 4-10. https://doi.org/10.1080/04419057.2000.9674181

Manajemen Operasional Daya Tarik Wisata Jatiluwih. (2018). Laporan Realisasi Pendapatan Tiket Masuk DTW Jatiluwih.

Poulios, I. (2014). Discussing Strategy in Heritage Conservation: Living Heritage Approach as an Example of Strategic Innovation. Journal of Cultural Heritage Management and Sustainable Development, 4(1), 16-34. https://doi.org/10.1108/JCHMST-10-2012-0048

Richardson, J. I., \& Fluker, M. (2004). Understanding and Managing Tourism. Australia: 


\section{Macrothink \\ International Journal of Social Science Research \\ ISSN 2327-5510 2019, Vol. 7, No. 1}

Pearson Education.

Sage, A. P. (1977). Interpretive Structural Modelling: Methodology for Large Scale Systems. New York: McGraw-Hill.

Saxena, J. P. (1992). Hierarchy and Classification of Program Plan Elements Using Interpretive Structural Modelling. System Practice, 5(6), 651-670.

Sunaryo, B. (2013). Kebijakan Pembangunan Destinasi Pariwisata: Konsep dan Aplikasinya di Indonesia. Yogyakarta: Gava Media.

UNEP \& WTO. (2005). Making Tourism More Sustainable, a Guide for Policy Makers. Madrid: UNEP \& WTO.

Wall, G., \& Black, H. (2005). Global Heritage and Local Problems: Some Examples from Indonesia. In D. Harrison \& M. Hitchcock (Eds.), the Politics of World Heritage: Negotiating Tourism and Conservation. London: Channel View Publications.

Widari, D. A. D. S. (2015). Perkembangan Desa Wisata Jatiluwih Setelah Penetapan Subak Sebagai Warisan Budaya Dunia (Thesis). Denpasar: Program Pascasarjana Universitas Udayana.

Wiranatha, A. S., \& Suryawardani, I. G. A. O. (2018). A Structural Model of Community-Based Agritourism Development at the World Heritage Site of Jatiluwih Rice Field Terrace in Tabanan, Bali. Global and Stochastic Analysis, 5(6), 547-563.

Yamashita, S. (2013). The Balinese Subak as World Cultural Heritages: In the Context of Tourism. Bali $2^{\text {nd }}$ Culture Congress. Denpasar.

\section{Copyrights}

Copyright for this article is retained by the author(s), with first publication rights granted to the journal.

This is an open-access article distributed under the terms and conditions of the Creative Commons Attribution license (http://creativecommons.org/licenses/by/4.0/). 